\title{
Casino capitalism in the era of COVID-19: Examining Macau's pandemic response
}

\author{
Loretta Lou \\ University of Macau \\ lorettalou@um.edu.mo
}

The published version of the paper can be found here.

Citation:

Lou, L. (2021), "Casino capitalism in the era of COVID-19: examining Macau's pandemic response", Social Transformations in Chinese Societies, Vol. ahead-of-print No. ahead-ofprint.

\begin{abstract}
Purpose

This purpose of this paper is to explain Macau's successful pandemic response through an analysis of its social, political, and economic landscapes. In particular, it focuses on the economic relief brought by casino capitalism in this era of COVID-19.
\end{abstract}

\section{Design/methodology/approach}

As mobility is highly restricted during the coronavirus pandemic, digital technologies have become central to ongoing social science research. Thanks to videoconferencing programmes such as Zoom, Facetime, and WhatsApp, I was able to carry out virtual interviews with thirteen local people from different sectors of Macau in July 2020. In addition to in-depth interviews, I also undertook an extensive review of the Macau government's pandemic policies.

\section{Findings}

This paper argues that the Macau government's swift and effective coronavirus policies are deeply intertwined with the urban fabric and political economy of the city's casino capitalism, which endowed the government with surplus funds and an infrastructure that enabled the implementation of an array of strict measures that few other countries could afford to subsidize. Among the factors that have led to Macau's extraordinarily low rates of COVID-19 infections and deaths are not only competent leadership but also the public's high compliance with mandatory health measures, the generous benefits and financial support for citizens and businesses, and the compulsory quarantine required of all incoming travellers, who are lodged in hotel rooms left empty when casino tourists stopped coming. All of these measures have been made possible by a political economy backed by the peculiarities of casino capitalism and its resultant tax revenues. 


\section{Originality}

While previous studies tend to emphasise the negative impacts of casino capitalism, this paper shows how tax revenues and infrastructure from the gambling industry can make a contribution to the host society in times of crisis.

\section{Research implications}

Future research could compare the case of Macau with other small but affluent economies (ideally, economies that do not depend on the gambling industry) to ascertain the role of casino capitalism in building up economic resilience. 
At the time of writing (17 December 2020), no active cases of COVID-19 have appeared in Macau for eight months in a row. Since Macau confirmed its first case in January 2020, it has had a total of only forty-six confirmed cases and no deaths. Despite being the poster child in the fight against COVID-19, the case of Macau has by and large been ignored while Taiwan, South Korea, and Hong Kong are lauded as exemplary, even though the latter two regions have recently been hit by the second and fourth waves of infections. The omission of Macau is not an isolated incident but a reflection of its long-standing marginalised status in East Asia. As culture critic Chin Pang Lei observes, geographical terms such as zhong gang tai and liang an san de (which include China, Taiwan, and Hong Kong) never encompass Macau. Macau has always been ignored. It is a city invisible on all fronts (Lei, 2018).

Still, given Macau's remarkable performance in containing the virus for a sustained period of time, its experience can serve as a point of reference for understanding successful responses to COVID-19, especially if we take into account all the risk factors confronted by Macau. With a population of 650,000 and an area of only 32.9 square kilometres, Macau is the world's most densely populated region. Prior to the coronavirus outbreak, the city welcomed nearly 40 million visitors from China and the rest of the world in 2019 (Macao Government Tourism Office, 2019, p. 13). Like Hong Kong, Macau also shares borders with mainland China, the original COVID-19 epicentre. In spite of these risk factors, so far there has been no community outbreak of the disease. How did Macau manage to keep the virus at bay?

In this article, I answer this question through an analysis of Macau's social, political, and economic landscapes. According to popular stereotypes, Macau people are 'obedient' to authority and are ready to accept face-covering and social-distancing rules without questioning them. As such, Macau's pandemic success is sometimes held up as a testament to the influence of Confucianism and authoritarianism, two of the most common explanations for compliance with rules in Asia. In section one, I refute this claim by situating Macau's 'docility' in the context of its historical and cultural particularities. I argue that their willingness to comply with rules is neither a result of Confucian values nor authoritarian rule but, rather, a manifestation of the Macau people's 'habitus' (Bourdieu, 1977) and their 'cultural intimacy' (Herzfeld, 2005). In section two, I start by discussing how Macau's COVID-19 policies were influenced by its experiences with SARS and Typhoon Hato, since research has demonstrated that lessons from past crises led to better preparedness. I then show that the measures and interventions put in place by the Macau government are deeply intertwined with the urban fabric and political economy of the city's casino capitalism- 'the process of stimulating economic growth through the proliferation of casinos' (Lo, 2009, p. 20) - which endowed the government with surplus funds and an infrastructure that enabled the implementation of much stricter measures than those other countries could afford to subsidize. Among the factors that have led to Macau's extraordinarily low rates of COVID19 infections and deaths are not only the competent leadership behind the Macau government's swift and effective coronavirus response but also the public's high compliance with mandatory health measures, the generous benefits and financial support for citizens and businesses, and the compulsory quarantine requirement for all incoming travellers, lodged in hotel rooms left empty by casino tourists who stopped coming. All these measures have been made possible by a political economy backed by the peculiarities of casino capitalism and its resultant tax revenues.

\section{Debunking the theses of 'Asian values' and 'authoritarianism'}


As the epicentres of the pandemic shifted from Asia to Europe and the United States, some pundits contended that the relative successes of some Asian countries in containing the spread of COVID-19 have to do with their unique 'Asian values'. For example, in an op-ed piece in the South China Morning Post, Ian Inkster, an East Asian specialist at SOAS University of London, remarked that the strong traditions of Confucianism and Buddhism in East Asian societies have given them an edge in the battle against the coronavirus (Inkster, 2020). Byung-Chul Han, a Korean-born German philosopher and cultural theorist, even went so far as to say that people in Asia are 'less rebellious and more obedient than in Europe' because they 'have an authoritarian mentality which comes from their cultural tradition [of] Confucianism' (Han, cited in Escobar, 2020).

Since the new coronavirus has become a global pandemic, arguments like these have been quickly taken up by mainstream media searching for a plausible explanation for the contrasting results between the East and the West (Escobar, 2020; Martin and Walker, 2020; Beech, 2020) — not least because such explanations conform to certain Orientalist preconceptions. This kind of cultural thesis is a mutation of another equally essentialist but more controversial debate. As the world witnessed how decisively China enacted lockdowns, 'the uneven performance of many democracies in containing the pandemic and mitigating its public health effects rekindles debates about the effectiveness of democratic rule compared to authoritarian regimes' (Croissant, 2020). However, the type of political model is hardly the only factor or the determining one that affects a country's performance in handling COVID19. As Rachel Kleinfeld points out, so far there is little evidence to suggest that there is 'a strong correlation between efficacy and regime type. While some autocracies have performed well, like Singapore, others have done very poorly, like Iran' (Kleinfeld, 2020). Most importantly, as democratic governments such as New Zealand, Iceland, South Korea, and Taiwan demonstrated success in handling the pandemic, myths about the authoritarian advantage were also debunked (Kingston, 2020, p. 2).

\section{'Docility' in an acquaintance society: Habitus and cultural intimacy in Macau}

Like Hong Kong, Macau is a hybrid regime that simultaneously has features of democracy and autocracy (Ieong and Wang, 2020, pp. 117-118). In this sense, the democratic-versusauthoritarian debate is not really applicable to these two Special Administrative Regions of China. Moreover, although a large part of Macau's political and cultural landscapes is shaped by semi-authoritarian policies under 'One Country, Two Systems', the ways that people behave are not determined by what political system they live in but are instead manifestations of their 'habitus' (Bourdieu 1977) and their 'cultural intimacy' (Herzfeld 2005). After all, pandemic control in the modern era depends far more on "voluntary compliance than on government enforcement' (Kleinfeld 2020).

While Bourdieu's concept of 'habitus' refers to disposition and deeply ingrained social practices, Herzfeld's concept of 'cultural intimacy' points to 'the recognition of those aspects of an officially shared identity that are considered a source of external embarrassment but that nevertheless provide insiders with their assurance of common sociality' (Herzfeld, 2005, p. 7). For many Macau locals, their 'habitus' and 'cultural intimacy' are embodied in their conservatism, their political apathy, and their social docility (Kwong, 2014; Lin, 2017). According to a longitudinal study of Macau's public culture, the desire for social harmony was so highly valued that $40 \%$ of the respondents said they preferred not to engage in any 
opposition movements (Kwong, 2014, p. 61). Even though some people are not afraid to speak out, hardly any space for real dissent and opposition exists in Macau, given that its civil society is dominated by 'government-backed and pro-Beijing groups and associations' (Lin, 2020:61).

In addition to the conservative environment, the Macanese's docility is sometimes attributed to their consensus that Macau is an 'acquaintance society' (shuren shehui) in which everyone knows one another (Fei, 2001). Whether or not Macau is actually an acquaintance society is beyond the scope of this paper, but the fact that many Macau people are convinced that they live in an acquaintance society not only increases their aversion to conflicts but also their willingness to follow norms and comply with rules. In the context of COVID-19, this quality is reflected in the Macanese's compliance with face-covering and social-distancing mandates as well as in their acceptance of many of the government's decisions. Unlike their counterparts in Hong Kong, there was no loud demand for closing borders and no opposition to the involvement of testing companies and medical staff from mainland China. There was no conspiracy theory circulating in Macau about China covertly collecting DNA samples through COVID-19 tests until such a theory hit the headlines in Hong Kong. Of course, this is also related to the differences between the societies in the level of political trust in their respective governments before the outbreak of COVID-19. After Hongkongers staged a series of protests in 2019, political trust in their government sank to a new low. In contrast, Macau people were sitting on the fence about their new chief executive and his new cabinet, who had taken office just one month before the pandemic began.

In any case, the Macanese's cooperation with their government's COVID-19 policies cannot be understood as a simple penchant for social harmony. Their cooperation is, in fact, a cumulative effect of multiple factors, such as the collective memories of SARS, the impact of Typhoon Hato, economic support from the government, and a relatively spacious living home environment, all of which have contributed to strong adherence to social-distancing regulations by the Macau people.

\section{COVID-19 and governmentality in Macau}

\section{Learning from the past: SARS and Typhoon Hato}

The COVID-19 pandemic not only unveils a society's underlying problems, it also points to 'the broader question of the relationship between governments and their constituent citizens' (Meyer and Sundqvist, 2020). According to Meyer and Sundqvist, there have been two main models of public health governance, but COVID-19 pandemic policies belong to neither. In the first model of governance, officials and experts are actively in charge while citizens remain passive. In the second model, citizens are critical of the government's decisions and demand to be involved in the production of knowledge and risk management. Meyer and Sundqvist argue that the current pandemic is a hybrid of the two models. On the one hand, governments expect their citizens to obey to the social-distancing rules (model 1); on the other, citizens have learned to become proactive and vigilant (model 2). To fight the pandemic, 'the government is obliged to delegate an important part of the management of the crisis to citizens' and rely on them to 'act "responsibly"' (Meyer and Sundqvist, 2020).

While this has been a steep learning curve for many countries in the West, people in China, Hong Kong, Taiwan, and Singapore already went through it once before in 2003. Since then, 
a culture of 'responsibilisation' has taken root in these societies, and handwashing and using face masks have become regular practices. Increasingly, studies have suggested that societies that are having the greatest success in containing the virus are the ones that were worst affected by the SARS epidemic in 2003 (Graham-Harrison, 2020; Kingston, 2020, p. 3). 'The memory of that crisis may have led to better preparedness, in government and among the population, and to a greater willingness among people to comply with restrictions on movement and daily life to prevent the spread of infection' (Graham-Harrison, 2020; see also Kingston, 2020, and other articles in this special issue).

Although Macau had only one recorded case of SARS back in 2003, the pain of witnessing the staggering death tolls in Hong Kong and China left a mark in Macanese memories. Therefore, when the first case of COVID-19 eventually arrived in the city, both the government and the general populace took it seriously and acted without delay. ${ }^{1}$

Besides SARS, the traumatic experience of Typhoon Hato in 2016, which caused significant damage to Macau, also heightened the government's sense of crisis, spurring it to take decisive actions during the early stages of the pandemic. According to a civil servant working for the Municipal Affairs Bureau, the Macau government was able to assure the public from the start that there was a sufficient stock of protective gear because the country had been accumulating masks, hazmat suits, gloves, and disinfectants ever since Typhoon Hato in case another emergency struck. Macau's case indicates that the government's response to the pandemic was conditioned not only by its past experience of SARS but also on lessons learned from previous disasters of an entirely different kind than diseases.

\section{Face masks and self-isolation: An embodiment of privileges}

In February 2020, Macau's Secretary for Social Affairs and Culture urged residents to 'control their own feet' by staying at home. In the same press conference, she insisted that closing the borders with China was not an option for Macau. Earlier that month, medical staff in Hong Kong had gone on a strike to demand that Carrie Lam close Hong Kong's borders with China. Although both places have similar concerns about the risk of continuous crossborder movement, there were hardly any objections in Macau. Overall, Macau residents have been very cooperative with the government's strategy to fight the disease.

Katrina ${ }^{2}$ a dual resident of Hong Kong and Macau, felt that Macanese self-discipline and pragmatic attitude have helped them win the battle against COVID-19. 'Macau people don't tend to politicise things. Most people don't think there is any ulterior motive when the government asked us to stay at home,' she said. At the time of the interview, Katrina was stranded in her Macau home while Hong Kong underwent another spike of community infection. She complained that many Hong Kong people were not as 'disciplined' as the Macanese because many of them defied the government's advice to stay at home. 'The Hong Kong government, of course, has many problems. But I fear that Hongkongers are opposing for the sake of opposing. After a year-long protest, many Hong Kong people have lost trust in their government'.

\footnotetext{
${ }^{1}$ As early as 5 January 2020, the Macau government formed an interdepartmental taskforce for what it called 'pneumonia of unknown cause'.

${ }^{2}$ To protect individual identities and their confidentiality, I use pseudonyms for all of my interlocutors.
} 
Are the Macanese really more disciplined than their Hong Kong counterparts? Or, as the stereotype goes, are they really more obedient to authority? In a previous section, I discussed this issue on a theoretical level with references to the concepts of 'habitus', 'cultural intimacy', and the perception of living in an acquaintance society. When I directed this question to my interlocutors, their answers were far more down to earth. While they agreed that political conformity is an indisputable fact, they disagreed that Macau people are more compliant with COVID-19 rules. Yasmin, a journalist and freelance tour guide, said she has not been wearing face masks since the peak passed in April because she felt very safe in Macau. Janet is a librarian in a public library. She complained to me that many elderly people had ignored the face-mask rule and come to the library without following the required Macao Health Code. ${ }^{3}$ 'I think you can't really generalise to say that Macau people are more disciplined than Hong Kong people. It depends on the person,' Janet insisted. Carmen, a desk researcher who was able to work from home for a couple of months, believed that it was the government's coherent and consistent measures that made it feasible for many Macau people to stay at home. When the government ordered a two-week closure of all casinos, it resulted in a series of knock-on effects. First, it removed the major incentive for tourists (from China) to come to Macau, which made it unnecessary for Macau officials to close the border with the mainland - a sensitive issue that required the government to balance the interests of multiple parties. ${ }^{4}$ Furthermore, since a large percentage of the Macau workforce is employed by the gaming industry (Lo, 2009, p. 25; Sheng and Gu, 2018, p. 76), a two-week closure allowed most people to stay home and work from there, which helped prevent the spread of infections. Together with the closures of nurseries, schools, and universities, these measures brought Macau to a temporary halt without an official lockdown.

Unlike Katrina, who thought Hongkongers' going-out and eating-out behaviours were signs of a 'lack of discipline', Carmen was sympathetic with them:

I know that being able to stay at home is a privilege. Not every job allows you to do that. I really enjoyed my stay-at-home time. I was able to work and relax in the comfort of my home, with air-conditioning twenty-four hours a day, seven days a week, because the Macau government has waived the electricity and water charges for residential users from March to May.

But I couldn't imagine staying at home the entire time if I lived in a subdivided flat. As you know, apartments in Macau are generally a lot bigger than those in Hong Kong. It's easier for us to cook at home so we don't need to eat out. But what about people who live in subdivided flats in Hong Kong? What about those who still need to go to work and don't have the conditions to cook at home? It's very sad to see Hong Kong people eating bento boxes on the street!

The guaranteed access to face masks in Macau at a time of a global shortage of personal protective equipment magnifies how privileged the Macanese are. By late January, the Macau government rolled out a rationing programme for surgical masks, which enabled local

\footnotetext{
${ }^{3}$ The Macao Health Code is similar to the health code system developed by the Chinese government in response to COVID-19. For more about the health code system in China, see Courtney (2020).

${ }^{4}$ To meet the demand of Macau's growing economy, a large number of imported workers, mostly from mainland China, were recruited to Macau over the past decade (Sheng and Gu, 2018, p. 74). The majority of these migrant workers live in Zhuhai and commute to Macau for work every day. Some are key workers who deliver essential frontline services. Therefore, on the issue of closing borders, Macau not only needs to consider politics but also practicalities, such as where migrant workers would be housed if the borders were closed.
} 
residents and anyone holding a valid work permit in Macau to buy ten masks for $\$ 8$ Macanese pataca (MOP) every ten days. Kevin, a consultant surgeon at the Hospital Centre S. Januario, commended this scheme: 'Even though we live in an age of advanced science and technology, the most effective ways to prevent infectious diseases are still handwashing, wearing masks, and social distancing.' Meanwhile, Hongkongers were seen queuing outside pharmacies only to be told that all masks were sold out. Several of my interviewees recalled sending boxes of masks to their Hong Kong friends and relatives. One of them said, 'The Hong Kong government is so incompetent that even my "blue-ribbon" relatives hate them now'. 5

Competent leadership has certainly played a pivotal role in the coordination of testing, tracing, imposing quarantines, controlling borders, and distributing face masks. Ho Iat Seng, the new Chief Executive of Macau since December 2019, has been praised for his competence in crisis management. Several of my interviewees said they felt lucky that COVID-19 hit Macau after Ho's predecessor Chui Sai-On left office: 'Macau people would be in deep trouble if Chui were in charge.' Despite having a PhD in Public Health from the University of Oklahoma, Chui lost support and trust from the public over a number of controversies during his tenure. Most notably, he was severely criticised for his slow reaction to Typhoon Hato, resulting in ten deaths and two hundred injuries. Ho's performance makes a sharp contrast with not only his predecessor but also with Hong Kong's Chief Executive Carrie Lam.

However, one downside of emphasising the role of competence is that instead of examining structural issues, the focus on leadership reinforces the legitimacy of an executive-dominated political system that was designed to bring 'economic prosperity and political stability [to Macau] without democracy' (Ieong, 2020, p. 5). ${ }^{6}$ This has led to fears that an administration heavily dominated by the executive branch would further reduce Macau's already shrinking civic space. Indeed, for the first time in twenty years, the government banned open-air photographic exhibitions and mass vigils for commemorating the victims of the 1989 Tiananmen Square crackdown, claiming that these gatherings would pose a threat to public health.

In the final section, I will further unpack why the Macau government was able to do what it did. I argue that the Macau government would not have been so decisive nor its quarantine measures so effective in keeping COVID-19 rates low if its political economy were not based on casino capitalism, which not only endowed Macau with a considerable budget surplus but also an urban fabric woven with plenty of empty hotels for self-isolation and mandatory quarantines for incoming travellers.

\section{Casino capitalism: an accidental boon to pandemic containment?}

If one only looks at how people conduct their everyday life, Macau seems to have already adapted to the 'new normal'. So-called staycations are booming and restaurants are getting busier and busier, with some of them being fully booked during weekends or even weeks in

\footnotetext{
${ }^{5}$ Wearing a blue ribbon has been a symbol used by supporters of the government and the police force during Hong Kong's democratic movement.

${ }^{6}$ According to Fong, 'The notion of executive dominance could be defined as the executive holding a dominant position vis-à-vis the legislature over the legislative process, i.e., the capacity of the executive to control the legislative agenda and get its proposal accepted by the legislature' (2014, p. 5).
} 
advance. However, a closer look at the numbers reveals that Macau's economic activities are far from having returned to the pre-COVID-19 'normalcy'. According to the Statistics and Census Service, Macau's gross domestic product (GDP) dropped by $67.8 \%$ for the second quarter of 2020 (Statistics and Census Service, 2020, p. 1). Gaming revenue sank to an alltime low. In June 2020, Macau recorded a gaming revenue of $\$ 716$ million MOP, a 97\% decline from the same month the year before (Macau News, 2020a). Despite this dramatic drop, middle-class Macanese have yet to feel the full impact of the economic hit. 'Some industries are definitely hit harder, and some people are more affected than others,' admitted Yasmin. 'But compared to other cities in the world, the sense of precarity is still very minimal in Macau because Macau is a very rich city.'

Fernando, an economist working for a government bureau, believes that the delayed sense of economic vulnerability may be due to Macau's low unemployment rate and the generous, timely financial-support measures. For example, each Macau residents have been issued a $\$ 13,000$ MOP consumption subsidy (a.k.a. 'spending vouchers') and free health vouchers since the start of the pandemic. While eligible employees and self-employed workers are entitled to cash support, small- and medium-sized enterprises can benefit from a combination of tax break, tax exemptions, subsidies, and interest-free loans. These forms of economic support would not have been possible if Macau had not accumulated a considerable surplus of tax revenues from the gaming industry over the past two decades. As Chief Executive Ho Iat Seng admitted, 'Thanks to the fiscal surplus from previous years, the government's reserves can cushion the economic disruptions brought by COVID-19.' With an abundant fiscal reserve, the government had less to worry about when imposing draconic measures like closing the casinos. This in turn has made residents feel that the government is committed to putting their lives before the economy.

In contrast to many countries, where tax bases have declined dramatically in recent decades (Erikson, 2020, p. 441), Macau has tens of billions of unused casino taxes sitting in its government coffers (Master, 2017). Since the Chinese government freed up Macau's gaming market in 2002, Macau has surpassed Las Vegas to become the largest gambling centre in the world. Subsequently, local service sectors such as real estate, hotels, restaurants, and retail have also profited from the gaming industry boom (Sheng and $\mathrm{Gu}, 2018$, p. 79). In 2013, Macau hit an all-time high in gaming revenue, totalling $\$ 360.8$ billion MOP, which is 'seven times that of the Las Vegas Strip' (Ngan, 2020, p. 11). Even though the gaming revenues have gone down slightly in recent years, the figures are still about four times that of Las Vegas, accounting for more than $80 \%$ of government revenues in Macau (Ngan, 2020, p. 11). This is because licensed casino operators in Macau are required to 'pay 35 percent casino tax on gross gaming revenues and not less than 2 percent to a public foundation for the promotion of cultural, social, economic, educational, scientific, academic and charity projects' (Lo, 2009, p. 25). This policy has endowed the Macau government's coffers with a sizeable reserve. According to the Macau Monetary Authority, by the end of 2019, the financial reserves of Macau stood at \$580.75 billion MOP (Macau News, 2020b).

In addition to their financial contributions, the casinos' integrated hotels and resorts have also played a crucial role in preventing the spread of COVID-19 by serving as 'quarantine hotels'. Since late February, anyone who has been to an area with a high incidence of coronavirus infections prior to their entry into Macau has been required to undergo quarantine and medical observation for fourteen days at a designated hotel. In terms of cost, the fee for room and board is waived for Macau residents, while nonlocals are asked to pay \$5,600 MOP for 
their two-week quarantine. By the end of May, the Macau government had spent $\$ 70$ million MOP on quarantine hotels.

Overall, Macau locals are pleased with results of the quarantine arrangements. Community members consider the direct transfer of returning travellers from checkpoints to quarantine hotels to be a safer option than self-isolation at home. Those who are under quarantine are also satisfied with the experience. 'The hotel was clean and I got three meals a day, all free of charge. I have nothing to complain about,' said Jenny, a student who returned to Macau in March from her boarding school in the UK.

In a recent commentary published in Nature Human Behaviour, medical anthropologist Susan Erikson argues that too much dependence on the private sector weakened the US's pandemic response (Erikson, 2020, p. 441). The case of Macau is perhaps one of the few counterexamples of this statement. While tax revenues from the gambling industry provide economic relief to Macau during this challenging time, the casino hotels serve as a 'spatial buffer' or 'first line of defence' against potential carriers of COVID-19. This positive aspect is worth exploring, as past studies tend to emphasise the negative impacts of the gaming industry on the host community (Chang, Lai and Wang, 2010; Hannigan, 2007; Simpson, 2016; Chu, 2015). Future research could compare the case of Macau with other small but affluent economies (ideally, economies that do not depend on the gambling industry) to ascertain the role of casino capitalism in building up economic resilience. ${ }^{7}$ Nonetheless, the side effects of casino capitalism should not be overlooked. In Macau, even though many people's livelihoods depend on casino tourism, the huge influx of tourists, the overinflated house prices, and the erosion of the city's once-tranquil small-town appeal (Lei 2020, p. 24) have triggered many grievances among the general populace. This is the contradiction of 'casino capitalism' (Lo, 2009), a double-edged sword that can either widen inequality or equip the government with the necessary resources to build infrastructure and expand social services. Thus, when COVID-19 was poised to spill over into Macau from China and other ravaged countries, threatening the health and lives of its citizens, the government already had the funds and infrastructure to expand its repertoire of health measures far beyond what any other country could do. As a result, Macau's rates of COVID-19 infections and deaths have been and remain extraordinarily low. Ho Iat Seng's cabinet has proved its capacity to handle a global pandemic, but it remains to be seen if his administration will make better, wiser use of the government budget in the future than previous administrations did.

\section{References}

Beech, H. (2020). "Tracking the coronavirus: how crowded Asian cities tackled an epidemic". New York Times. 17 March. Available at:

https://www.nytimes.com/2020/03/17/world/asia/coronavirus-singapore-hong-kongtaiwan.html [accessed 28 September 2020].

Bourdieu, P. (1977). Outline of a Theory of Practice. Cambridge: Cambridge University Press.

Chang, J., Lai, C. and Wang, P. (2010). "Casino regulations and economic welfare". Canadian Journal of Economics/Revue canadienne d'économique, 43 (3), pp.1058-1085.

\footnotetext{
${ }^{7}$ I thank Nick Or for raising this point.
} 
Available at: https://onlinelibrary.wiley.com/doi/full/10.1111/j.1540-5982.2010.01606.x [accessed 10 December 2019].

Chu, C. L. (2015). "Spectacular Macau: visioning futures for a world heritage city". Geoforum, 65, pp. 440-450. Available at: https://doi.org/10.1016/j.geoforum.2015.06.009 [access 12 December 2019].

Courtney, C. (2020). "COVID-19 and China's Health Code System". [Blog post]. Somatosphere: Science, Medicine, and Anthropology. Available at: http://somatosphere.net/forumpost/covid-19-china-health-code-system [accessed 30 September 2020].

Croissant, A. (2020). "Democracies with preexisting conditions and the coronavirus in the Indo-Pacific". The Asan Forum. Available at: http://www.theasanforum.org/democracieswith-preexisting-conditions-and-the-coronavirus-in-the-indo-pacific/?dat $=$ [accessed 21 September 2020].

Statistics and Census Service (DSEC) (2020). "Gross domestic product: 2nd quarter 2020”. Government of Macao Special Administrative Region Statistics and Census Service. Available at: https://www.dsec.gov.mo/getAttachment/e8fd3a02-779e-4e51-a1342dd1e402584e/E_PIB_FR_2020_Q2.aspx [accessed 22 September 2020].

Escobar, P. (2020). "Confucius is winning the COVID-19 war". Asia Times. https://asiatimes.com/2020/04/confucius-is-winning-the-covid-19-war/ [accessed 21 September 2020].

Erikson, S. (2020). "Pandemics show us what government is for". Nature Human Behaviour, 4 (5), pp. 441-442. Available at: https://www.nature.com/articles/s41562-020-0871-4 [accessed 21 September 2020].

Fei, X. (2001). From the Soil: The Foundations of Chinese Society, A Translation of Fei Xiaotong's Xiangtu Zhongguo. With an introduction and epilogue by G.G. Hamilton and W. Zheng. Berkeley: University of California Press.

Fong, B.C.H. (2014). Executive-legislative disconnection in post-colonial Hong Kong: the dysfunction of the HKSAR's executive-dominant system, 1997-2012. China Perspectives, 1, pp. 5-14. Available at: https://doi.org/10.4000/chinaperspectives.6357 [accessed 28 September 2020].

Graham-Harrison, E. (2020). "Experience of Sars a key factor in countries' response to coronavirus". The Observer. 15 March. Available at:

https://www.theguardian.com/world/2020/mar/15/experience-of-sars-key-factor-in-responseto-coronavirus [accessed 28 September 2020].

Hannigan, J. (2007). “Casino cities”. Geography Compass, 1 (4), pp. 959-975. Available at: https://doi.org/10.1111/j.1749-8198.2007.00044.x [accessed 28 September 2020].

Herzfeld, M. (2005). Cultural Intimacy: Social Poetics in the Nation-State. London:

Routledge. 
Ieong, M.U. (2020). “Introduction”. In: Ieong, M.U. (Ed.), Macau 20 Years After the Handover: Changes and Challenges Under "One Country, Two Systems", pp. 1-8. London: Routledge.

Ieong, M.U. and Wang, H. (2020). "Media usage pattern and media effects on attitudes toward the Umbrella Movement: a comparative study between college students from Macau and Mainland China". In: Ieong, M.U. (Ed.), Macau 20 Years After the Handover: Changes and Challenges Under "One Country, Two Systems", pp. 107-120. London: Routledge.

Inkster, I. (2020). "In the battle against the coronavirus, East Asian societies and cultures have the edge". South China Morning Post. Available at:

https://www.scmp.com/comment/opinion/article/3079176/battle-against-coronavirus-eastasian-societies-and-cultures-have [accessed 21 September 2020].

Kleinfeld, R. (2020). "Do authoritarian or democratic countries handle pandemics better?" Blog post, 31 March. Carnegie Endowment for International Peace. Available at: https://carnegieendowment.org/2020/03/31/do-authoritarian-or-democratic-countries-handlepandemics-better-pub-81404 [accessed 28 September 2020].

Kingston, J. (2020). “Introduction". The Asia-Pacific Journal Special issue: Japan Focus, 18 (14). Available at: https://apjjf.org/-Jeff-Kingston/5417/article.pdf [accessed

21 September 2020].

Kwong, Y.H. (2014). "Protests against the welfare package for chief executives and principal officials: Macao's political awakening”. China Perspective 4, pp. 61-65. Available at: https://journals.openedition.org/chinaperspectives/6588 [accessed 28 September 2020].

Lei, C.P. (2018). 《隱形澳門：被忽略的城市與文化》 [Invisible Macau: The Ignored City and Culture]. Taipei: Walkers Cultural.

Lin, Z. (2017). "Re-imagined communities in Macau in cyberspace: resist, reclaim and restructure." Chinese Journal of Communication 10 (3), pp. 229-245. Available at: https://doi.org/10.1080/17544750.2017.1325763 [accessed 28 September 2020].

Lin, Z. (2020). "Contextualized emotional mobilization: playful protests and resentful protests in Macau in the Internet age". In: Ieong, M.U. (Ed.), Macau 20 Years After the Handover: Changes and Challenges Under "One Country, Two Systems", pp. 57-75. London: Routledge.

Lo, S. (2009). "Casino capitalism and its legitimacy impact on the politico-administrative state in Macau". Journal of Current Chinese Affairs, 38 (1), pp. 19-47. Available at: https://journals.sub.uni-hamburg.de/giga/jcca/article/view/12/12.html [accessed 28 September 2020].

Macao Government Tourism Office (2019). "Macao tourism performance highlights". Macao Tourism Industry Net, Macao Government Tourism Office. Available at: https://industry.macaotourism.gov.mo/e-publication/MTTS2019/2019 MGTO StatisticsCh2.pdf [accessed 28 September 2020]. 
Macau News. (2020a). “Macao casinos' GGR for June drops by 97\%”. Available at: https://macaunews.mo/macao-ggr-for-june-drops-by-97-year-on-year/ [accessed 22 September 2020].

Macau News. (2020b). “Macau's financial reserves gain 5.6\% in 2019”. Available at: https://macaunews.mo/macaus-financial-reserves-gain-5-6-in2019/?fbclid=IwAR2AzPKPctLq0f2Xq6A_7RhBqrEquL8kE_r4nsnljnY59ZUFpbcfIrfXfo8 [accessed 22 September 2020].

Martin, T.W. and Walker, M. (2020). "East vs. west: coronavirus fight tests divergent strategies". Wall Street Journal. 13 March. Available at: https://www.wsj.com/articles/eastvs-west-coronavirus-fight-tests-divergent-strategies-11584110308 [accessed 31 May 2020].

Master, F. (2017). "Macau's unused billions: booming casino taxes sit in government coffers." Reuters. 12 September. Available at: https://uk.reuters.com/article/uk-macaueconomy/macaus-unused-billions-booming-casino-taxes-sit-in-government-coffersidUKKCN1BN0GW?il=0 [accessed 21 September 2020].

Meyer, M. and Sundqvist, G. (2020). "Sharing responsibilities, coping with the coronavirus: why Swedish and French response strategies are not that different". [Blog post]. Somatosphere: Science, Medicine, and Anthropology. Available at: http://somatosphere.net/2020/sharing-responsibilities.html/ [accessed 21 September 2020].

Sheng, M. and Gu, C. (2018). "Economic growth and development in Macau (1999-2016): The role of the booming gaming industry". Cities,75, pp.72-80. Available at: https://www.sciencedirect.com/science/article/pii/S0264275117308995. [accessed 28 September 2020].

Simpson, T. (2008). "Macau, capital of the 21st century?" Environment and Planning D: Society and Space, 26 (6), pp. 1053-1079. Available at: https://doi.org/10.1068/d9607 [accessed 28 September 2020].

Statistics and Census Service (DSEC) (2020). "Gross domestic product: 2nd quarter 2020". Government of Macao Special Administrative Region Statistics and Census Service. Available at: https://www.dsec.gov.mo/getAttachment/e8fd3a02-779e-4e51-a1342dd1e402584e/E_PIB_FR_2020_Q2.aspx [accessed 22 September 2020]. 